\title{
Environmental Regulations and Rules: United Nations Perspective and the Nigeria Experience
}

*Dr. FASHUYI OLUGBENGA

Federal University of Technology Akure Ondo State Nigeria, Nigeria Email: olugbeinga@gmail.com

\begin{tabular}{l}
\hline A R T I C L E I N F O: \\
\hline Article history: \\
Received 5 April 2018 \\
Accepted 25 April 2018 \\
Available online 27 June 2018 \\
\hline Keywords: \\
Agenda 21; \\
Bunkering; \\
Oil Spill; \\
Nigeria; \\
Cook Stove.
\end{tabular}

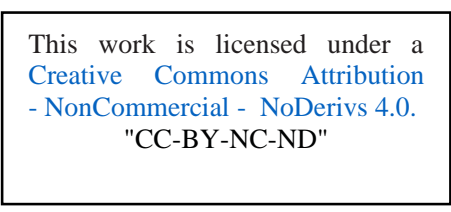

\begin{abstract}
A B S T R A C T
This research reviewed the Nigeria's environmental laws within the context of Agenda 21 at the three levels of water, forest degradation and solid waste management with the intent of evaluating the importance of Agenda 21 on environmental sustainability in the country. Furthermore, the study examined the Nigeria's environmental laws to determine its effectiveness. In this way, the study provided information on the effectiveness and extent of United Nations interventions on environmental issues in Nigeria thereby revealing the gap between such interventions and actual environmental challenges of the country.
\end{abstract}

JOURNAL OF CONTEMPORARY URBAN AFFAIRS (2019), 3(1), 62-66.

https://doi.org/10.25034/ijcua.2018.4683

www.ijcua.com

Copyright (@) 2018 Journal Of Contemporary Urban Affairs. All rights

reserved

\section{Introduction}

With the advances made in globalization resulting in progress in international integration and interchange of world views, global environmental concerns have assumed a more germane dimension. It has therefore become easier to realize that local environmental challenge in certain parts of the world have widespread reverberations on some other parts of the globe. In fact, it has been pointed out that recent global issue in form of depletion of the Ozone layer and global warming are the result of greenhouse gases and other complex processes (Blodgett, 2004). These have further resulted to major environmental devastations and called the attention and interventions of the United Nations. These interventions precipitated two major and important events, vis-à-vis: the Rio conference of 1972 and the United Nations Conference on Environment and Development, 1992. At these meetings, global environmental issues were dialectically analyzed and a broad template for Earths sustainability (the Agenda 21) was realized and adopted.

Agenda 21 discussed Earth's environmental problems and suggested solutions within the frame and peculiarity of each member state of the United Nations. It is within the context of these suggested solutions that Nigeria (a United Nation member state) re-defined her constraints, priorities and environmental laws in order to meet up with United Nations criteria for Earth's sustainability.

In view of the foregoing, this research intends to review Nigeria's environmental laws within the context of Agenda 21 with the intent of evaluating the importance of Agenda 21 on environmental sustainability in the country. The study will also examine the Nigeria's environmental laws to determine its

*Corresponding Author:

Federal University of Technology Akure Ondo State Nigeria, Nigeria

E-mail address: olugbeinga@gmail.com 
effectiveness. In this way, the study reflects on the United Nations interventions in Nigeria thereby taking a position on the extent and effectiveness of such interventions on the environmental milieu of the country. Moreover, this study examined the Nigeria environmental challenges at the three major levels of water problems, waste management and forest degradation and the issues involved at these levels are discussed in different sections of this work.

\section{Environmental Regulations and Rules \\ 2.1 United Nations Perspectives}

Environmental laws stems from the recognition that the natural environment is fragile and needed special protection (Environmental law, Mold and Water Damage Expert, 2018). Following this important realization, it became imperative to protect the Earth natural assets.

Addressing these challenges the United Nations (UN), summoned the 'Stockholm conference' which converged at Rio de Janeiro in 1972. This was succeeded by another major meeting in 1992 referred to as the United Nation's Conference on Environment and Development (UNCED) or simply Earths summit. These world conferences were targeted at addressing the Earth's environmental challenges. According to the UN the major environmental challenge in Africa and Nigeria inclusive, are related to issues of drought, flooding, deforestation, and widespread poverty (Table 1).

Table1: United Nations perspective.

\begin{tabular}{|cc|l|}
\hline & \multicolumn{1}{|c|}{$\begin{array}{c}\text { Environmental issue } \\
\text { addressed } \\
\text { Not addressed }\end{array}$} \\
\hline - & 1 & Drought \\
\hline$\circ$ & 2 & Water hyacinth \\
\hline - & 3 & Flooding \\
\hline - & 4 & Air pollution \\
\hline$\circ$ & 4 & Cook stove \\
\hline - & 6 & Deforestation \\
\hline$\circ$ & 7 & Solid and coastal Erosion \\
\hline - & 8 & Loss of bio- diversity \\
\hline - & 9 & Fresh water availability \\
\hline - & 10 & Degradation of soil \\
\hline$\circ$ & 11 & Oil pollution \\
\hline - & 12 & Flooding \\
\hline - & 13 & Wide spread poverty \\
\hline
\end{tabular}

\subsection{Nigeria Perspective}

Nigeria is a tropical country located in western Africa on the Gulf of Guinea and has total area of $923,768 \mathrm{~km}^{2}$.

\subsubsection{Perspective of the Federal Government of Nigeria on Environmental Challenges.}

Literature has shown that environmental challenges in Nigeria, at their primary levels, manifest in three major forms vis-à-vis: water problems, forest degradation, and solid waste management (Ogunleye, 2004). Nigeria (Fig. 1) is largely an agrarian economy until more recent times when the economy relied heavily on petroleum resources for development.

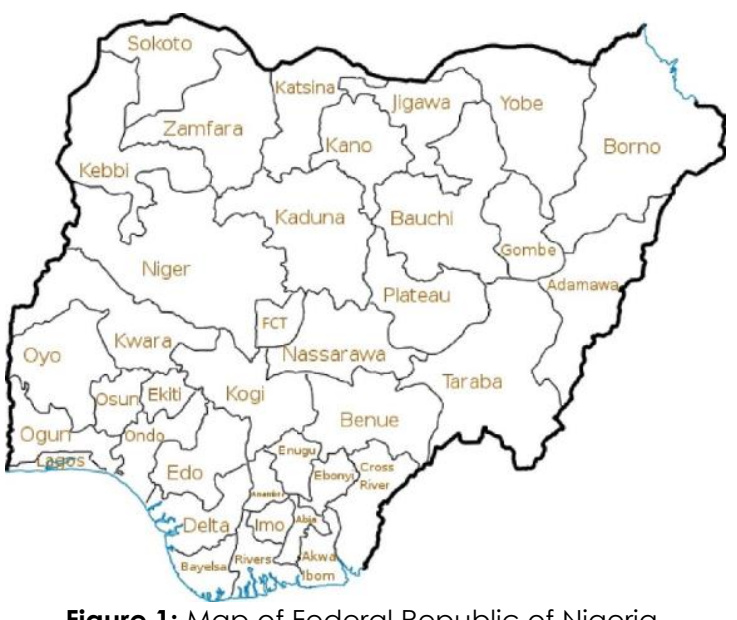

Figure 1: Map of Federal Republic of Nigeria.

At the secondary level (Table 2), these challenges are recognized by the Federal Government of Nigeria (FGN) in relation to: drought, flooding, air pollution, deforestation, loss of bio diversity, fresh water availability, and widespread poverty.

Table 2: Showing Federal Government Perspective of environmental challenges in Nigeria.

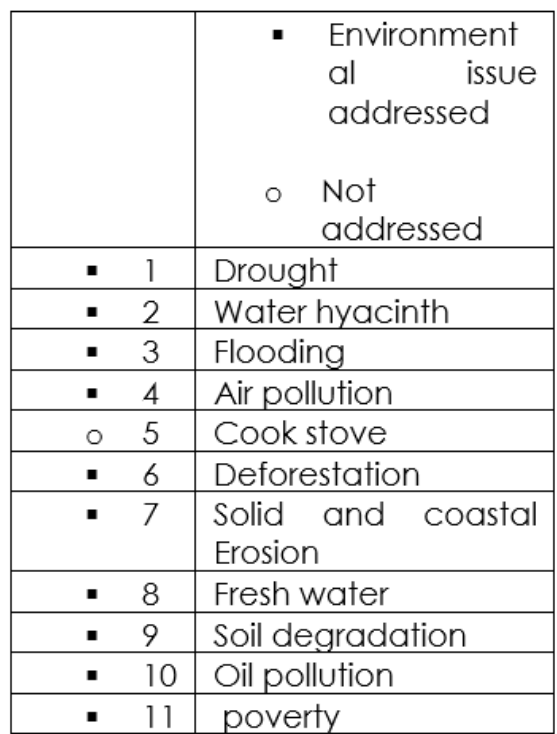

This study examines the current trend in environmental challenges in the country, vis-àvis the UN recommendations and their 
interconnectedness at the three primary levels of environmental concerns.

\subsubsection{The Objectives of the Federal Government of Nigeria and United Nations Recommendations}

In response to UN recommendation at UNCED 1992, the Federal Government of Nigeria (FGN) organized a regional workshop in Abuja titled: 'the implementation of Agenda 21 in Africa' in 1993. After the workshop, the Federal Government established a National Advisory Committee (NAC) on the implementation of the Agenda. Prior to the UNCED however, environmental concern in Nigeria has been generally monitored by the Federal Environmental Protection Agency (FEPA). In preparation for UNCED 1992, the guidelines and standard approved by FEPA was reviewed through Decree 59 in 1992. In so doing, the decree legalized proposed guidelines and standards for environmental pollution control, the regulations on effluent limitations, pollution abatement in industries and the regulations for the management of social and hazardous waste. Furthermore, the Environmental Impact Assessment (EIA) was also enacted in 1992 to serve as a tool for integrating environmental issues in all major activities throughout the country.

After UNCED 1992, the Nigeria government created its own version of the UN recommendation. In so doing, the FGN mapped out strategies towards the implementation of Agenda 21, and identified the following as major environmental challenges confronting the nation. These are: deforestation, drought and desertification, solid and coastal erosion, water pollution, oil pollution, water hyacinth invasion, loss of bio-diversity, flooding, urban decay and industrial pollution (FGN, 1992). In the bid to redress these challenges, the FGN took initial measures such as integrating the environment into development planning and decision making. The strategy to do this includes: (i). improving the provision of EIA through Decree 86 of 1992; and (ii) adopting the system of National Accounting (AC) to adequately reflect the extent to which economic development activities have increased or decreased environmental pollution and natural resources on which future economy and social developments depends.

\section{Deforestation (Forest Degradation) and Water Pollution}

Most of the environmental problems in Nigeria, either ranging from deforestation, urban decay, urban poverty and desertification have their roots in oil pollution (due to oil spillage) as a result of lassez-faire attitude in the petroleum resource exploration. In fact, statistics indicate that corrosion of pipelines and tanker accounts for $50 \%$ of oil spills while sabotage, oil production operations and non-functional production equipment accounts for $28 \%, 21 \%$ and $1 \%$ respectively (FGN, 1992). As a result, immense proportions of the mangrove forest have been destroyed. More so, an estimated $5 \%$ to $10 \%$ of Nigerian mangrove ecosystem has been wiped out thus implying deforestation and loss in the ecosystem (Fig. 2-3). Moreover the rain and mangrove forests which previously occupied 7,400 square kilometers of land have disappeared. These are coupled with soil contamination and freshwater crisis resulting from oil spills in many parts of the country.

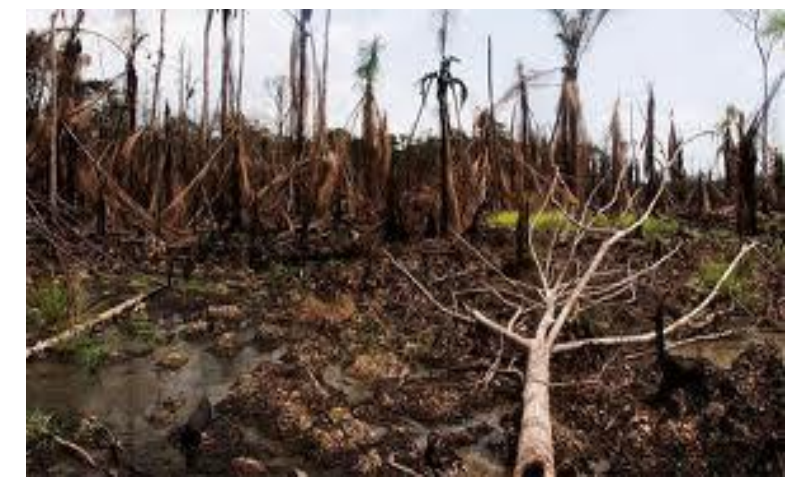

Figure 2: waste land.

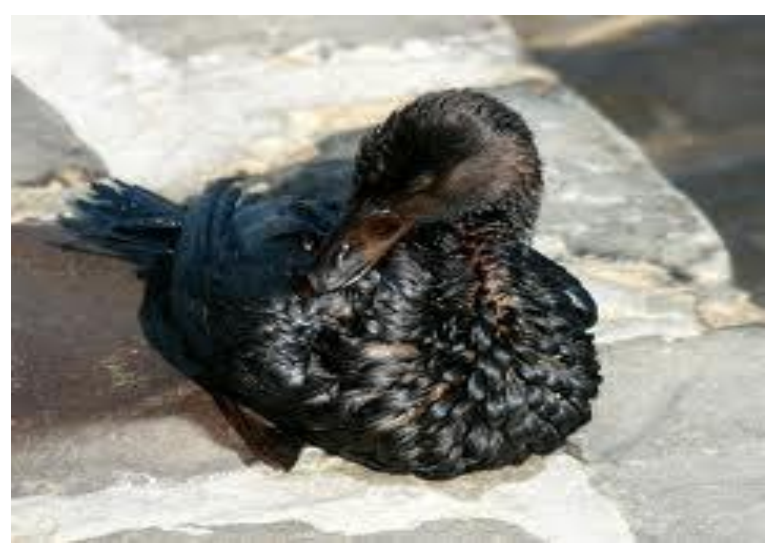

Figure 3: Loss in the ecosystem.

Mangrove forest has also resulted into urban poverty as the forest has served as major source of wood for indigenous people and vital to their subsistence. Thus the indigenous people are forced to derelict settlements since they have no economic resource to provide settlements 
fitted with even the most basic amenities. This view was buttressed in literature and it was observed that $33-67 \%$ of urban poor in Less Developed Countries (LDC) such as Nigeria lives in urban core settlements characterized by shanty housing and decaying environments (Olotuah, 2000) (Fig.4). Consequently, these indigenous folks took to sabotaging the petroleum pipelines- 'bunkering' amongst other vices as means of alleviating their poverty (fig.5). Moreover, it has also been observed that much of industrial effluent and other hydro-carbons from petroleum resource exploration have been carelessly released into the atmosphere, and have consequently induced greenhouse gases (Lorraine, 2004). In many instances, these have resulted in climatic changes culminating to desertification and drought.

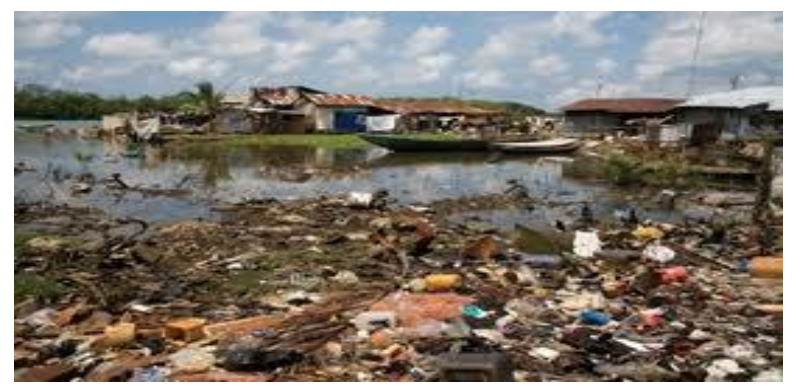

Figure 4: Slum housing.

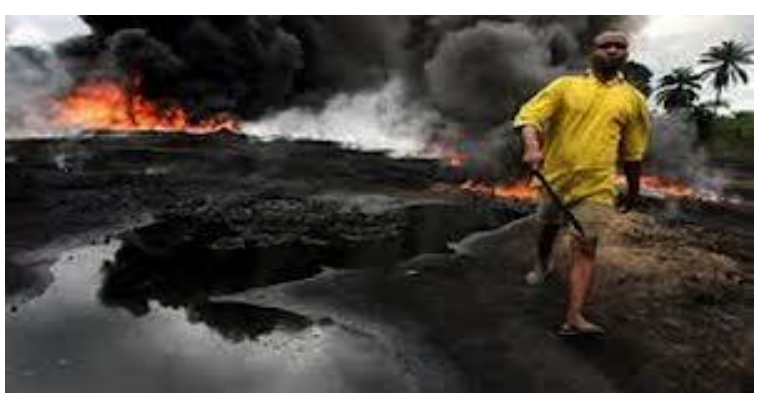

Figure 5: Bunkering-illegal tapings into pipelines.

\subsection{Solid Waste Management}

Much of the cause of solid waste in Nigeria owes to industrialization, heavy refuse dumps, urban consumerism pattern and air pollutants emitted from factories. Indeed air pollution is copious in many parts of the world (Oshrieh \& Valipour, 2018). Statistics obtained in the 1980's by two research teams showed that $70-90 \%$ of residents of cities in Nigeria such as Ibadan, Benin, Enugu and Kaduna failed to use officially designed facilities for disposing their refuse (Obi, 2002). In fact, the refuse are often piled randomly at any available location. Thus within a short time, an amorphous settlement character evolves, drainage patterns are blocked and derelict houses are built on flood plains leading to flooding.

\subsection{United Nations Recommendation and Federal Government Interventions}

The United Nations recommendations on environmental concerns in Africa and Nigeria have been documented in details in Agenda 21 of UNCED 1992. These concerns focused on vast array of environmental issues ranging from drought to widespread poverty as earlier explained. However, the United States Environmental Protection Agency (EPA) realized the need for concern on the environmental import of the growing use of cook stoves on indoor and outdoor spaces in Africa before its impact contaminate the global environment (Manda, 2017). This issue was not realized in the United Nations. This aspect is of vital importance as almost every urban and suburban dweller in Nigeria and many other Less Developed Countries (LDC) uses the cook stoves (Federal Republic of Nigeria, 2002; Obi, 2017). Furthermore, environmental challenges of: water hyacinth, solid and coastal erosion, oil pollution, flooding were reinforced in FGN interventions but were neglected in the UN specification for environmental challenges in Nigeria (Table 3 below).

Table 3: Showing areas of non-intervention by FGN and United Nations on environmental issues as it concerns Nigeria.

\begin{tabular}{cl}
$\begin{array}{c}\text { FEDERAL } \\
\text { GOVERNMENT } \\
\text { OF NIGERIA }\end{array}$ \\
\hline COOK STOVE & $\begin{array}{l}\text { Cook stove } \\
\text { Water hyacinth } \\
\text { Solid and coastal Erosion } \\
\text { Oil pollution }\end{array}$ \\
\hline
\end{tabular}

\section{Conclusions}

The FGN has 'packaged' its version of Agenda 21 in form of formal pronouncement backed by law. However despite all the retinue of the FGN policies, Government interventions are ineffective in many ways and up till now, the issues of flooding and decaying urbanism, shanty housing resulting from unplanned settlements and poverty are still prominently severe in the country. This ineffectiveness is most probably because FGN interventions come through the instrumentality of law and other legal paraphernalia available to Government constituency whereas the concept of private sector participation in taking environmental decisions have been largely ignored. As a result, some authors have painted Government effort as cosmetic (Ogunleye, 2004). Lending credence to this view, the Federal Republic of 
Nigeria, has appropriated coordination of Government intervention on environmental issues within the country as a difficult problem (Federal Republic of Nigeria, National Policy on the Environment, 2016). Evidences from literature have also attributed this difficulty to the fact that the wealth of information that could be used to manage sustainable development in the country cannot be accessed in useful format. This is coupled with the general lack of awareness on the importance of the environment among majority of the people in the country. The study however recommends that FGN policies as it regards the environment should be re-tailored to mitigate environmental consequence of the cook stoves in Nigeria.

\section{Acknowledgement}

This research did not receive any specific grant from funding agencies in the public, commercial, or not-for-profit sectors.

\section{Conflict of interests}

The author declares no conflict of interest.

\section{References}

Blodgett, J.E. (2004). Environmental protection: New approaches. NY. Nova Publishers. https://www.novapublishers.com/catalog/ product_info.php?products_id $=1274$

Environmental Law (2016). Framework for assessing and improving Law for sustainability. Martin, P, Boer, B, Slobodian L. (Eds). A legal component of a natural resource governance framework. https://www.iucn.org/theme/environment al-law

Ogunleye, F. (2004). Environmental sustainability in Nigeria: The "awareness" imperative. African Issues, 31 (1/2) 41-52. https://doi.org/10.1017/S1548450500006600

Federal Government of Nigeria (1992). Environmental protection agency (amendment) decree. http://www.nigerialaw.org.201992.htm. Accessed on: 25 Feb. 2018.

Federal Republic of Nigeria (2002). Government white paper on the report of the presidential committee on urban development and housing.

https://www.emeraldinsight.com/doi/full/1

108/JFM-12-2015-0037?mobileUi=0

Federal Republic of Nigeria, National Policy on the Environment (2016). Federal Ministry of Environment. http://environment. Gov.ng/media/attachments/2017/09/22/r evised-nationalpolicy-on-the-environmentfinal-draft . Accessed on: 23 March 2018

Lorraine, M. E. (2004). The global politics of the environment. Palgrave Macmillan: New York.

https://nyupress.org/books/9780814722183/

Mandal, A. \& Byrd, H. (2017). Density, Energy and Metabolism of a proposed smart city. Contemporary Urban Affairs (JCUA), 1(2), 57-60. Doi: 10.25034/ijcua.2017.3648

Clark, V.E., \& Phil, D. (2016). The politics of the Nigerian oil industry: Transparency and accountability for sustainable development in the Niger-Delta. American International Journal of Contemporary Research. 6(4); 76-82. www.aijcrnet.com/journals/Vol_6_No_4_A ugust 2016/9.pdf

Obi, I. (2017). An agenda for the management of contemporary sustainable houses. Journal of Contemporary Urban Affairs. 1 (2), 33-37. DOl: 10.25034/ijcua.2017.3646

Olotuah, A.O. (2000). The challenge of housing in Nigeria Effective housing in te $21^{\text {st }}$ Century. Akinbamijo, O.B et al. (EDs) Environmental Forum. Federal University of Technology, Akure Nigeria. www.ijhssi.org/papers/vol7(4)/Version1/B0704011116.pdf

Oshrieh, R., \& Valipour, E. (2019). The Role Of Urban Density And Morphology In The Air Pollution Of Tehran Metropolitan. Journal of Contemporary Urban Affairs (JCUA), 3(1), 38-43. Doi: 10.25034/ijcua.2018.4680. 